\title{
Macro- and microelements in serum and seminal plasma as biomarkers for bull sperm cryotolerance
}

\author{
Maja Zakošek Pipan ${ }^{1 *} \mathbb{0}$, Petra Zrimšek ${ }^{2}$, Breda Jakovac Strajn ${ }^{3}$, Katarina Pavšič Vrtač ${ }^{3}$ Tanja Knific ${ }^{3}$ and \\ Janko Mrkun ${ }^{1}$
}

\begin{abstract}
Background: Wide variation in fertility rates is observed when using frozen bull semen, even when the bulls have met quality standards for semen production. Therefore, a simple and reliable test to assess the freezing potential of bull semen based on the analysis of fresh semen or blood would be of great value. Attention is now turning to assessment of seminal plasma components such as proteins and elements. In the present study, the concentrations of macro- and microelements in fresh bull semen plasma and in serum and their correlation with quality characteristics of fresh semen and with semen quality after freezing and thawing were determined. Ejaculates were collected from 30 mature bulls, and semen volume, concentration, sperm motility, morphology, tail membrane integrity, plasma membrane permeability and DNA fragmentation were determined on the day of collection and after freezing and thawing. The concentrations of macroelements ( $\mathrm{Na}, \mathrm{Mg}, \mathrm{K}$ and $\mathrm{Ca}$ ) and microelements (Cu, $\mathrm{Fe}, \mathrm{Zn}$ and $\mathrm{Se}$ ) were determined in the seminal plasma and serum. The semen samples were classified into satisfactory and unsatisfactory groups according to the fresh semen quality.
\end{abstract}

Results: Zinc and Se levels measured in serum were associated with almost all fresh and frozen-thawed semen quality characteristics, while Fe levels were associated only with acrosomal defects in fresh semen. Zinc and Fe levels in fresh seminal plasma were associated with various quality characteristics of fresh and frozen-thawed semen, while Se level in fresh seminal plasma was not associated with any of the semen quality characteristics.

Conclusions: Microelements were shown to be useful as biomarkers involved in the analysis of bull sperm quality and could be used as an additional tool to predict bull semen quality after freezing and thawing. Our results confirm that the analysis of Zn and Se levels in serum and Zn, Cu and Fe levels in fresh seminal plasma can provide information to discriminate between bull semen samples with spermatozoa with high or low cryotolerance.

Keywords: Blood serum, Bull semen, Cryopreservation, Microelements, Quality, Seminal plasma

*Correspondence: maja.zakosekpipan@vf.uni-lj.si

${ }^{1}$ Clinic for Reproduction and Large Animals, Veterinary Faculty, University of Ljubljana, Gerbičeva 60, 1000 Ljubljana, Slovenia

Full list of author information is available at the end of the article

\section{Background}

Sperm quality evaluation is of economic importance in breeding management because it allows the selection of bulls with good reproductive performance. Bulls are evaluated for health, libido and mating ability, and their semen is evaluated for volume, sperm concentration, motility, viability, morphology and the ability to withstand freezing and thawing processes $[1,2]$. Semen used for artificial insemination (AI) of cows should be of high

c) The Author(s) 2021. This article is licensed under a Creative Commons Attribution 4.0 International License, which permits use, sharing, adaptation, distribution and reproduction in any medium or format, as long as you give appropriate credit to the original author(s) and the source, provide a link to the Creative Commons licence, and indicate if changes were made. The images or other third party material in this article are included in the article's Creative Commons licence, unless indicated otherwise in a credit line to the material. If material is not included in the article's Creative Commons licence and your intended use is not permitted by statutory regulation or exceeds the permitted use, you will need to obtain permission directly from the copyright holder. To view a copy of this licence, visit http://creativeco mmons.org/licenses/by/4.0/. The Creative Commons Public Domain Dedication waiver (http://creativecommons.org/publicdomain/ zero/1.0/) applies to the data made available in this article, unless otherwise stated in a credit line to the data. 
quality. However, conventional estimates of fresh semen quality are not sensitive enough to distinguish between samples that differ in predictive quality after storage [2]. Moreover, the fertility of frozen bull semen varies widely, even if the bulls have met the quality standards for semen production [3]. The most accurate method for testing bull fertility is in vivo insemination of many fertile females, but this method is time consuming, expensive for routine use, and allows only a limited number of bulls to be tested at any given time [4]. Therefore, developing a simple, inexpensive, accurate, precise, and reliable test to assess the freezing potential of bull semen based on the analysis of fresh semen or blood would be of great value. Attention is now turning to the evaluation of other components of semen, such as fertility-associated proteins [5, 6] and macro- and microelements [7-9]. Elements are known to play an important role in bovine health and reproduction [10], and several studies have shown that element imbalance affects the reproductive performance of bulls and that elements such as calcium (Ca), copper $(\mathrm{Cu})$, iron $(\mathrm{Fe})$, magnesium $(\mathrm{Mg})$, selenium $(\mathrm{Se})$ and zinc $(\mathrm{Zn})$ are essential for reproduction and that their deficiency can lead to degenerative changes in spermatogenesis [7, 11-13]. In humans, routine seminal plasma assessment includes the analysis of some microelements, such as $\mathrm{Zn}$ and Se, which are associated with sperm quality because of their antioxidant properties [14,15].

Recently, enrichment of a sperm extender with Se nanoparticles at a concentration of $1.0 \mu \mathrm{g} / \mathrm{mL}$ was shown to improve bull sperm quality after thawing and consequently increase in vivo fertility rates by reducing apoptosis, lipid peroxidation and cryopreservation-induced sperm damage [7]. Moreover, our previous study in boars showed that microelements are involved in boar sperm quality and could serve as an additional tool to predict sperm quality after storage [16].

The aim of the present study was to determine the concentrations of macro- and microelements in fresh bull seminal plasma and serum and assess the relationships of these factors with sperm quality characteristics in fresh semen and in semen after freezing and thawing.

\section{Methods}

\section{Experimental animals}

Semen ejaculates were obtained from 30 mature (2-3 years old) and healthy breeding bulls kept in a local AI center (Agriculture and Forestry Institute Ptuj, Slovenia). We obtained one ejaculate per bull, and all bulls underwent a regular health check immediately prior to semen collection. Only bulls that were healthy were selected for the study. Semen collection was performed in October and November. All bulls included in the experiment were Simmental cattle, and they were in a regular semen collection program for insemination purposes and kept under standard conditions regarding feeding and management. According to Slovenian legislation (National Assembly of the Republic of Slovenia, 2013) covered by Directive 2010/63/EU (The European Parliament and the Council, 2010), ethical approval was not required for the experiments because only noninvasive procedures were used in this study.

\section{Blood collection}

According to Slovenian veterinary regulations, all breeding bulls must be examined annually for various diseases. Therefore, as part of the regular examination, blood was taken from the bulls by venipuncture with a vacutainer needle and $10 \mathrm{~mL}$ plain red top tubes. Two red top tubes were collected from each bull, and approximately $16 \mathrm{ml}$ blood was collected. The blood samples for microelement analysis were left at room temperature for $30 \mathrm{~min}$ and then centrifuged at $1500 \mathrm{~g}$ at $4{ }^{\circ} \mathrm{C}$ for $15 \mathrm{~min}$. No visible hemolysis was observed in the samples taken. The blood serum was then immediately separated, aliquoted and stored at $-80{ }^{\circ} \mathrm{C}$ until the macro- and microelement concentrations were assayed.

\section{Collection of semen and seminal plasma preparation}

Semen samples were obtained from adult breeding bulls on a regular collection schedule using a teaser bull and an artificial vagina. After collection of the samples, $1 \mathrm{~mL}$ of the semen was used for initial semen evaluation (motility and sperm concentration). For the initial analysis, motility was determined subjectively under an optical phase microscope (Olympus CX31/41) and the concentration was determined using a photometer (Photometer SDM 5, Minitüb, Germany). Based on the initial sperm concentration, the raw ejaculate was diluted in BullXcell extender (IMV Technologies, France) containing bidistilled water, TRIS, glycerol, citric acid, sugars, buffers, antibiotics, and fresh egg yolk at a ratio of 1:4 to achieve a concentration of $15 \times 10^{6}$ total sperm per $0.25 \mathrm{~mL}$ insemination dose. Semen straws (IMV Technologies, France) were filled according to routine procedures using an IS4 machine (IMV Technologies, France), placed in an insulated box (to slow the temperature drop) and stored in a refrigerator at $4{ }^{\circ} \mathrm{C}$. Straws from each ejaculate were frozen $6 \mathrm{~h}$ after dilution and then stored in liquid nitrogen at $-196{ }^{\circ} \mathrm{C}$. Samples were evaluated after thawing at $37^{\circ} \mathrm{C}$ for $30 \mathrm{~s}$ in a water bath, and they were thawed at least 1 week after freezing and analyzed for post-thaw characteristics.

Semen samples were centrifuged at $800 \mathrm{~g}$ for $10 \mathrm{~min}$ at room temperature. The supernatants were removed and centrifuged again at $13,000 \mathrm{~g}$ for $15 \mathrm{~min}$ at $4{ }^{\circ} \mathrm{C}$ to separate 
seminal plasma [16]. Seminal plasma was then aliquoted and frozen at $-80{ }^{\circ} \mathrm{C}$ until assayed for macro- $(\mathrm{Na}, \mathrm{K}$, $\mathrm{Mg}, \mathrm{Ca}$ ) and microelements ( $\mathrm{Fe}, \mathrm{Cu}, \mathrm{Zn}$ and $\mathrm{Se})$.

\section{Sample preparation and basic semen characteristics}

Motility and progressive motility in fresh and frozen semen samples were determined with a computerassisted motility analyzer (AndroVision, Minitüb, Germany) using an optical phase microscope (Olympus CX31/41 and BX series) with a Leja counting chamber (Minitüb, Germany). The software was set using the manufacturer's recommendation, with a slight adjustment to allow for clear identification of all spermatozoa. Settings were configured as follows: 10 fields, region of particle control 10-18 $\mu \mathrm{m}$, depth of field $20 \mu \mathrm{m}$ and temperature of the microscope plate $37-37.5{ }^{\circ} \mathrm{C}$. Spermatozoa with (amplitude of lateral head) ALH $<1.5$ and straight-line velocity (VSL) < 12 were considered immotile (otherwise considered motile), spermatozoa with VSL $<48$ and with a curvilinear velocity $(\mathrm{VCL})<60$ were considered locally motile (otherwise considered progressively motile), spermatozoa with a radius $>9$ and radius $<90$ and rotation $>0.7$ were considered to have circular motility, and spermatozoa with a VCL $<90$ were considered slow motile (otherwise considered fast motile). A $10 \mu \mathrm{l}$ aliquot of the prewarmed semen sample $\left(5 \mathrm{~min}\right.$ at $\left.37^{\circ} \mathrm{C}\right)$ was placed on a prewarmed Leja chamber $\left(37-37.5^{\circ} \mathrm{C}\right)$, and pictures of ten fields were taken $(100 \times)$. For the reliability of the analysis, each measurement was performed twice.

Concentrations of raw and diluted semen before freezing were measured using a photometer (Photometer SDM 5, Minitüb, Germany) according to Indriastuti et al. [17].

The morphology and viability of 200 spermatozoa in fresh and frozen semen samples were assessed using eosin-nigrosin staining (Morphology Stain, Society for Theriogenology). Acrosome defects were also assessed using the oil immersion objective of a light microscope. A total of 200 sperm cells per slide were counted to distinguish between normal acrosome and acrosome abnormalities, such as absence of the acrosome, swelling or thickening, especially at the anterior tip of the sperm cell, and irregularities in the shape of the acrosome.

Samples were divided into two groups according to the quality characteristics of fresh semen based on the rules on conditions for the breeding of domesticated animals (Official Gazette of the Republic of Slovenia, No. 51/07 and 35/15; EVA 2001-2311-0094):

1. Satisfactory group (group SAT; $N=15$ ), which met all the requirements for satisfactory semen: motility $\geq$
$75 \%$, progressive motility $\geq 60 \%$, morphologically normal spermatozoa $\geq 75 \%$.

2. Unsatisfactory group (UNSAT group; $N=15$ ), which did not meet at least one of the above requirements for satisfactory semen characteristics.

\section{Specific semen characteristics Hypoosmotic swelling test (HOST)}

A HOST was used to assess the integrity of the caudal membrane as a test of sperm function. Ten microliters of semen sample were gently mixed with $100 \mu \mathrm{L}$ of hypoosmotic solution $\left(150 \mathrm{mOsm} / \mathrm{kg}\right.$ sodium citrate $\times 2 \mathrm{H}_{2} \mathrm{O}$ and fructose), both at $37^{\circ} \mathrm{C}$. After incubation at $37{ }^{\circ} \mathrm{C}$ in warm water for one hour, 200 spermatozoa per sample were examined under a light microscope at a magnification of $\times 400$. Spermatozoa were classified as HOST positive if they showed signs of swelling (swollen head and coiled tails).

\section{DNA fragmentation}

DNA integrity was assessed using a commercial assay (Sperm Bos-Halomax; Halotech DNA SL, Spain) based on a sperm dispersion test specifically designed for bull semen. Semen samples were processed according to the manufacturer's instructions. Briefly, to a vial containing $50 \mu \mathrm{L}$ of liquid low melting point agarose, $25 \mu \mathrm{L}$ of the semen sample was added at $37{ }^{\circ} \mathrm{C}$. The pretreated slides provided with the commercial assay were placed on a chilled glass plate at $4{ }^{\circ} \mathrm{C}$. Two microliters of the cell suspension were applied to the treated area of the chilled slide and covered with a coverslip for $5 \mathrm{~min}$. The coverslip was then carefully removed, and the slides were placed in $10 \mathrm{~mL}$ of the lysing solution at room temperature for $5 \mathrm{~min}$. Finally, the slides were washed in distilled water for $5 \mathrm{~min}$ and dehydrated in sequential ethanol solutions for 2 min each (70, 90, and 100\%). After drying, the samples were stained with a commercial fluorescence microscopy green staining kit (Halotech DNA, Spain) according to the instructions. Sperm chromatin dispersion was assessed using a fluorescence filter (Olympus U-MNIBA3; excitation at $497 \mathrm{~nm}$ and emission at $520 \mathrm{~nm})$ at $400 \times$ magnification (Olympus BX40). At least 300 spermatozoa were counted per semen sample, and samples were examined in duplicate.

The spermatozoa were divided into two groups according to the form of the halo effect. Group 1 contained spermatozoa with normal halo effects, i.e., intact DNA in which there was a clearly visible halo around the head, such as the diameter of the nucleus, and Group 2 contained spermatozoa with small, absent, or large halo effects. 


\section{Analysis of macro- and microelements}

Microwave digestion of the samples was performed using a MARS 5 Microwave Acceleration Reaction System (CEM, Matthews, NC). Seminal plasma samples (0.4-1 mL) and blood serum samples $(1 \mathrm{~mL})$ were transferred into a $100 \mathrm{~mL}$ Teflon vessel, and $3 \mathrm{~mL} \mathrm{65 \%} \mathrm{nitric}$ acid, $0.5 \mathrm{~mL} \mathrm{30 \%} \mathrm{hydrogen} \mathrm{peroxide} \mathrm{and} 4.5 \mathrm{~mL}$ Milli-Q water were added. The samples were digested in a closed 12 vessel microwave system at $200{ }^{\circ} \mathrm{C}$ for $30 \mathrm{~min}$. After cooling to room temperature, the solutions were diluted with Milli-Q water, and the concentrations of elements were determined by inductively coupled plasma mass spectrometry (Varian 820-MS, Mulgrave, Australia). Argon was used as the carrier gas, and the isotopes ${ }^{57} \mathrm{Fe}$, ${ }^{63} \mathrm{Cu},{ }^{66} \mathrm{Zn}$, and ${ }^{78} \mathrm{Se}$ were selected as analytical masses in inductively coupled plasma mass spectrometry (ICP-MS) normal sensitivity mode. A collision reaction interface (CRI) was used for measurements of Se to reduce common polyatomic interferences.

\section{Statistical analysis}

Statistical analysis was performed using R statistical software, version 3.5.2 (R Foundation for Statistical Computing, Vienna, Austria, 2018). A P value $<0.05$ was considered as significant. The results of semen characteristics and micro- and macroelements in seminal plasma and blood serum are presented with basic descriptive statistics.

Statistical comparison of the results obtained on fresh semen and after freezing thawing for each semen characteristic, macro- and microelement in SAT and UNSAT groups as well as between macro- and microelement in blood serum and seminal plasma was performed with Wilcoxon rank sum test, since the data were not normally distributed in all groups. Correlations between macroand microelements in blood serum and seminal plasma were assessed with Spearman's rank correlation coefficients, and Holm adjusted $\mathrm{P}$ values were used to determine statistical significance.

Multivariate linear regression analysis was used to test whether the concentrations of $\mathrm{Fe}, \mathrm{Se}$ and $\mathrm{Zn}$ in blood serum and seminal plasma significantly predicted the characteristics of fresh and frozen-thawed semen. These elements were selected based on significant correlations with semen quality characteristics. To better meet the normality assumption, we used a log transformation of the variable acrosome defects and a cubic transformation of the variable's motility, normal tail membrane integrity, normal morphology, progressive motility, and viability. Multicollinearity was tested with variance inflation factors and values $<5$ were considered below the critical level. The normality assumption of the models was evaluated using the quantile-quantile plots of the residuals.

\section{Results}

Semen quality characteristics of bull semen samples in the satisfactory and unsatisfactory groups

The median concentration of spermatozoa in the semen ejaculates was $1.48 \times 10^{9} \mathrm{sperm} / \mathrm{mL}$, with a lower quartile of $1.03 \times 10^{9}$ sperm $/ \mathrm{mL}$ and an upper quartile of $2.02 \times 10^{9} \mathrm{sperm} / \mathrm{mL}$. Characteristics of semen quality in satisfactory (SAT) $(\mathrm{N}=15)$ and unsatisfactory (UNSAT) $(\mathrm{N}=15)$ groups for fresh semen samples and for semen samples after freezing and thawing are included in Table 1.

\section{Concentration of elements measured in fresh seminal plasma and in blood serum}

Concentrations of elements were measured on the day of collection in seminal plasma and in blood serum and are presented in Table 2.

The concentration of Fe in fresh seminal plasma was the only element in seminal plasma that was significantly higher in the SAT group than in the UNSAT group $(\mathrm{P}=$ 0.0186; Fig. 1a). The concentrations of $\mathrm{Zn}$ and Se measured in blood serum were significantly higher in the SAT group than in the UNSAT group $(\mathrm{P}=0.0001$ and $\mathrm{P}=$ 0.0006, respectively; Fig. 1b, c).

\section{Correlation between element concentrations in seminal plasma and their concentrations in blood serum samples} A statistically significant correlation between the concentrations of elements in blood serum and in seminal plasma was found only for $\mathrm{Cu}$ and $\mathrm{Na}$. Both correlations were statistically significant $(\mathrm{P}<0.001)$ and very strong, with Spearman's $\rho$ values of 0.8834 for $\mathrm{Cu}$ and 0.8220 for $\mathrm{Na}$.

\section{Results of the multivariate regression model including elements}

Association between elements in fresh seminal plasma and the characteristics of fresh and frozen-thawed semen characteristics

The relationship between the concentrations of microelements in fresh seminal plasma and the characteristics of fresh and frozen-thawed semen was analyzed using a multivariate linear regression model. The results are summarized in Table 3. Fe was significantly associated with motility, progressive motility, the proportion of spermatozoa with acrosomal defects, and DNA fragmentation. Fe concentration was positively associated with motility and progressive motility, whereas it was negatively associated with acrosomal defects and DNA fragmentation. The values described above refer to fresh semen. In frozen-thawed 
Table 1 Semen quality characteristics of bull semen samples for the satisfactory group and unsatisfactory group

\begin{tabular}{|c|c|c|c|c|c|c|}
\hline \multirow[t]{3}{*}{ Semen characteristics (\%) } & \multicolumn{6}{|c|}{ Fresh semen } \\
\hline & \multicolumn{3}{|c|}{ Satisfactory group $(\mathrm{N}=15)^{\mathrm{a}}$} & \multicolumn{3}{|c|}{ Unsatisfactory group $(\mathrm{N}=15)^{\mathrm{a}}$} \\
\hline & Median & Lower quartile & Upper quartile & Median & Lower quartile & Upper quartile \\
\hline Motility & 85.00 & 85.00 & 90.00 & 60.00 & 50.00 & 60.00 \\
\hline Progressive motility & 75.00 & 70.00 & 77.50 & 40.00 & 30.00 & 52.50 \\
\hline Viability & 91.50 & 90.25 & 94.13 & 76.25 & 67.38 & 85.38 \\
\hline Normal morphology & 86.00 & 83.00 & 89.00 & 68.50 & 50.75 & 77.50 \\
\hline Acrosome defects & 2.50 & 1.25 & 3.25 & 5.00 & 3.25 & 11.75 \\
\hline Normal tail membrane integrity & 93.00 & 91.50 & 96.00 & 82.50 & 74.00 & 87.50 \\
\hline DNA fragmentation & 5.83 & 3.58 & 7.25 & 9.83 & 7.00 & 13.25 \\
\hline \multirow[t]{3}{*}{ Semen characteristics (\%) } & \multicolumn{6}{|c|}{ Frozen-thawed semen } \\
\hline & \multicolumn{3}{|c|}{ Satisfactory group $(\mathrm{N}=15)$} & \multicolumn{3}{|c|}{ Unsatisfactory group $(\mathrm{N}=15)$} \\
\hline & Median & Lower quartile & Upper quartile & Median & Lower quartile & Upper quartile \\
\hline Motility & 80.00 & 74.00 & 85.00 & 53.00 & 48.25 & 68.25 \\
\hline Progressive motility & 60.00 & 57.13 & 64.75 & 32.50 & 20.63 & 51.50 \\
\hline Viability & 89.25 & 85.13 & 90.88 & 64.00 & 58.38 & 82.75 \\
\hline Normal morphology & 81.00 & 74.75 & 84.00 & 60.50 & 41.50 & 72.00 \\
\hline Acrosome defects & 6.50 & 5.75 & 9.75 & 13.00 & 8.75 & 17.25 \\
\hline Normal tail membrane integrity & 90.50 & 86.75 & 93.50 & 73.50 & 67.75 & 79.75 \\
\hline DNA fragmentation & 8.50 & 5.42 & 9.25 & 15.67 & 11.75 & 20.6 \\
\hline
\end{tabular}

${ }^{a}$ For all measured semen characteristics, statistically significant differences between satisfactory and unsatisfactory groups were observed ( $\left.P<0.05\right)$ in fresh and frozen-thawed semen

Table 2 Concentration of elements measured in seminal plasma and in blood serum on the day of collection

\begin{tabular}{|c|c|c|c|c|c|c|}
\hline \multirow[t]{2}{*}{ Elements (mg/L) } & \multicolumn{3}{|c|}{ Seminal plasma } & \multicolumn{3}{|l|}{ Serum } \\
\hline & Median & Lower quartile & Upper quartile & Median & Lower quartile & Upper quartile \\
\hline $\mathrm{Na}$ & 3387.82 & 2842.02 & 3429.06 & 3387.82 & 3101.11 & 3434.56 \\
\hline $\mathrm{Mg}$ & 25.72 & 23.64 & 61.32 & 22.07 & 20.28 & 24.34 \\
\hline K & 231.75 & 192.87 & 1081.99 & 187.51 & 161.36 & 199.91 \\
\hline $\mathrm{Ca}$ & 103.78 & 96.38 & 255.10 & 93.09 & 81.05 & 97.45 \\
\hline $\mathrm{Fe}$ & 2.66 & 2.19 & 2.88 & 2.26 & 2.05 & 2.71 \\
\hline $\mathrm{Cu}$ & 0.87 & 0.33 & 1.05 & 0.90 & 0.77 & 1.05 \\
\hline $\mathrm{Zn}$ & 1.10 & 0.96 & 3.48 & 3.53 & 3.09 & 4.12 \\
\hline $\mathrm{Se}$ & 0.09 & 0.07 & 0.31 & 0.49 & 0.43 & 0.61 \\
\hline
\end{tabular}

semen, Fe was positively associated with viability and negatively associated with DNA fragmentation. Zn was negatively associated with acrosome defects. There were no statistically significant associations between semen quality characteristics and Se concentrations.

\section{Association between elements measured in blood serum} and the characteristics of fresh and frozen-thawed semen The results of the multivariable regression analysis for the elements measured in blood serum are summarized in Table 4. Selenium was associated with almost all semen characteristics except acrosome defects in fresh and frozen-thawed semen and DNA fragmentation in fresh semen. The association with DNA fragmentation in frozen-thawed semen was negative, and all other quality characteristics were positively associated with Se concentration. Similarly, Zn was significantly associated with most semen quality characteristics. However, it was not associated with progressive motility and viability in fresh semen and 

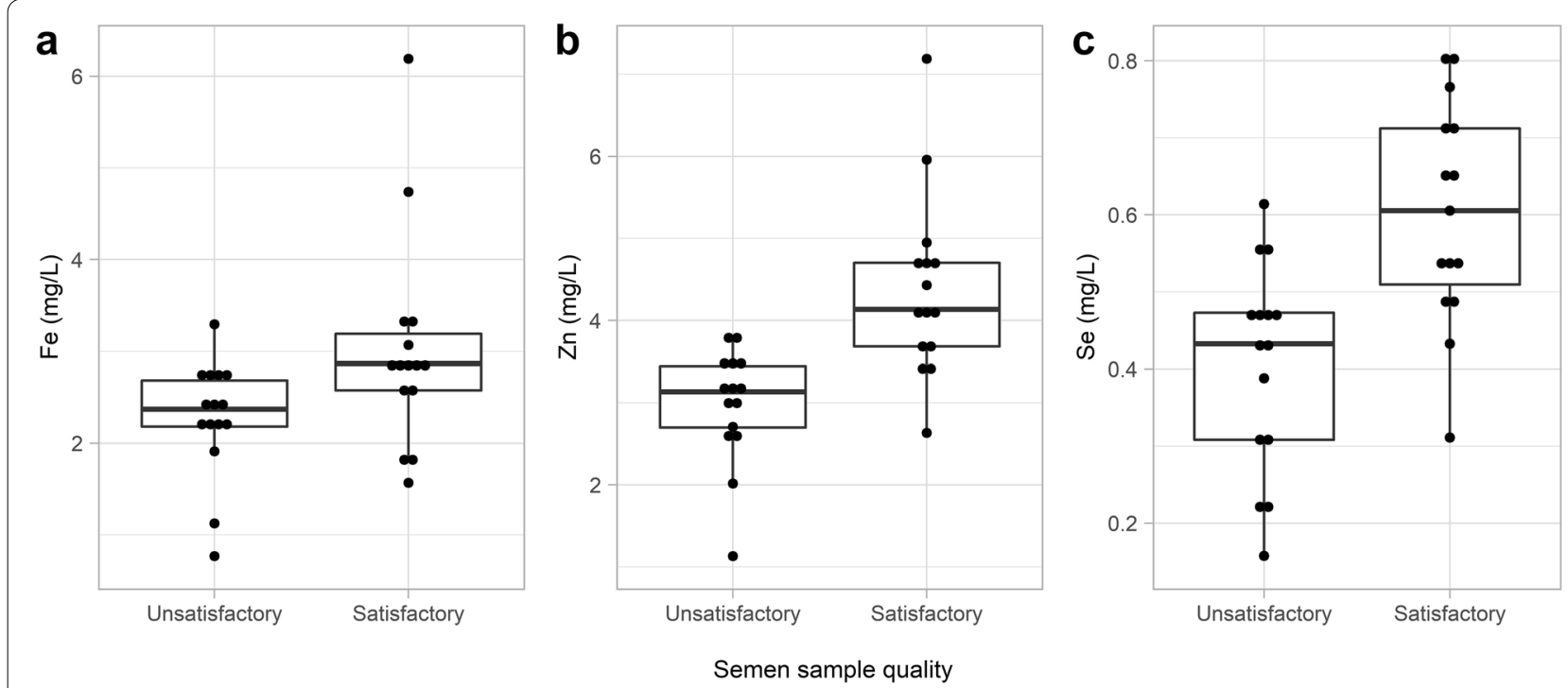

Fig. 1 Concentration of Fe in fresh seminal plasma (a) and concentration of $\mathrm{Zn}(\mathbf{b})$ and Se (c) in blood serum in the satisfactory and unsatisfactory semen samples

normal tail membrane integrity, but it was negatively associated with the proportion of spermatozoa with acrosomal defects $(\mathrm{P}=0.0494)$. Fe measured in blood serum was significantly negatively associated only with DNA fragmentation in fresh semen.

\section{Discussion}

The results show an association between element levels in fresh bull seminal plasma and serum and sperm quality characteristics on the day of collection and after freezing and thawing. $\mathrm{Zn}$ and Se measured in serum were associated with almost all quality characteristics of fresh and frozen-thawed semen. In this study, differences were also found between bulls that met all criteria of semen characteristics (SAT) and bulls that did not meet at least one of the criteria of sperm characteristics (UNSAT) on the day of collection according to the concentration of $\mathrm{Zn}$ and Se in blood serum and Fe in seminal plasma. Data comparisons with the results of other studies are limited because few studies have measured microelements in

Table 3 Multivariate analysis for semen quality characteristics of fresh and frozen-thawed semen and elements Fe, Se and Zn measured in seminal plasma on the day of collection

\begin{tabular}{|c|c|c|c|c|c|c|}
\hline \multirow{3}{*}{$\begin{array}{l}\text { Variables } \\
\text { Semen } \\
\text { characteristics (\%) }\end{array}$} & \multicolumn{6}{|c|}{ Elements in seminal plasma (mg/L) } \\
\hline & \multicolumn{2}{|l|}{$\mathrm{Fe}$} & \multicolumn{2}{|l|}{ Se } & \multicolumn{2}{|l|}{$\mathrm{Zn}$} \\
\hline & $\beta(95 \% \mathrm{Cl})$ & $\mathbf{P}$ & $\beta(95 \% \mathrm{Cl})$ & $\mathbf{P}$ & $\beta(95 \% \mathrm{Cl})$ & $P$ \\
\hline \multicolumn{7}{|l|}{ Fresh semen } \\
\hline Motility $^{a}$ & $1,30,610(38,101-2,23,118)$ & 0.0075 & $-1,26,431(-1,164,930$ to $9,12,069)$ & 0.8044 & $61,517(-58,790$ to $1,81,823)$ & 0.3029 \\
\hline Progressive motility ${ }^{\mathrm{a}}$ & $1,19,776(56,976-1,82,575)$ & 0.0006 & $-77,622(-7,82,609$ to $6,27,364)$ & 0.8227 & $42,553(-39,118-1,24,223)$ & 0.2940 \\
\hline Acrosome defects ${ }^{b}$ & $\begin{array}{l}-0.4749(-0.8642 \text { to } \\
-0.0855)\end{array}$ & 0.0188 & $2.3681(-2.0026$ to 6.7388$)$ & 0.2756 & $-2.0780(-1.0140$ to -0.0013$)$ & 0.0494 \\
\hline DNA fragmentation & $\begin{array}{l}-1.6851(-3.1603 \text { to } \\
-0.2099)\end{array}$ & 0.0268 & -1.9652 ( -18.5260 to 14.5956$)$ & 0.8092 & $-1.3558(-3.2743$ to 0.5627$)$ & 0.1583 \\
\hline \multicolumn{7}{|l|}{ Frozen-thawed semen } \\
\hline Viability ${ }^{a}$ & $1,14,891(24,909-2,04,872)$ & 0.0143 & $-1,56,982(-1,167,111$ to $8,53,146)$ & 0.7519 & $72,103(-44,917$ to $1,89,124)$ & 0.2165 \\
\hline DNA fragmentation & $\begin{array}{l}-3.4984(-5.7577 \text { to } \\
-1.2391)\end{array}$ & 0.0038 & $-5.7146(-31.0774$ to 19.6481$)$ & 0.6471 & $-1.0197(-3.9579$ to 1.9185$)$ & 0.4820 \\
\hline
\end{tabular}

${ }^{a}$ Cubic transformation

${ }^{\mathrm{b}}$ Log transformation 
the blood serum and seminal plasma of bulls to determine their influence on semen quality characteristics $[4,7,9,18-20]$. Studies on dietary supplementation of microelements and their influence on semen quality or addition of some of the microelements directly into the semen extenders were of highest interest to the researchers [21-26]. The results of dietary supplementation with Se or parenteral administration of Se had contradictory results. In some studies, no difference in semen quality was found after supplementation [27, 28], which may be related to the fact that mineral supplements commonly fed to livestock are commercially available in inorganic form. It is now known that trace minerals are present in the body almost entirely as organic complexes or chelates [29]. Organic trace mineral element sources may be more bioavailable, possibly by reducing negative interactions that could affect their efficiency of conversion to a physiologically active form $[19,30]$. In a study in which organic Se was supplemented in food and feed to buffalo bulls for three months, the semen quality characteristics (ejaculate volume, sperm motility, concentration, and morphology) were significantly improved [19]. In addition, researchers have found that the addition of Se directly into semen extenders improved postthaw semen characteristics $[7$, 31].

Selenium measured in fresh seminal plasma was associated with the proportion of spermatozoa with acrosome defects in fresh semen, consistent with the results of increased sperm acrosome integrity and number of sperm bound to the zona pellucida when Se was added to the fertilization medium [20].

In our study, Se measured in blood serum was associated with almost all the characteristics in fresh semen and with all the characteristics of frozen and thawed semen and therefore could serve as a good predictor of semen quality after freezing and thawing. Since Se is involved in normal spermatogenesis and represents an essential component of a number of selenoproteins (e.g., glutathione peroxidase 4-GPX4), its concentration in blood is crucial for the normal development of spermatozoa. GPX4 activity is highest during male germ cell development [32]. When Se concentrations are low during the final stages of spermatogenesis, GPX4 activity is decreased, leading to higher concentrations of active peroxides that can cause oxidative injury that can accumulate and lead to delayed viability impairment [33].

Table 4 Multivariate analysis for semen quality characteristics of fresh and frozen-thawed semen and elements Fe, Se and $\mathrm{Zn}$ measured in blood serum on the day of collection

\begin{tabular}{|c|c|c|c|c|c|c|}
\hline \multirow{3}{*}{$\begin{array}{l}\text { Variables } \\
\text { Semen } \\
\text { characteristics (\%) }\end{array}$} & \multicolumn{6}{|l|}{ Elements in blood serum (mg/L) } \\
\hline & \multicolumn{2}{|l|}{$\mathrm{Fe}$} & \multicolumn{2}{|l|}{ Se } & \multicolumn{2}{|l|}{$\mathrm{Zn}$} \\
\hline & $\beta(95 \% \mathrm{Cl})$ & $\mathbf{P}$ & $\beta(95 \% \mathrm{Cl})$ & $\mathbf{P}$ & $\beta(95 \% \mathrm{Cl})$ & $\mathbf{P}$ \\
\hline \multicolumn{7}{|l|}{ Fresh semen } \\
\hline Motility $^{a}$ & $80,738(-39,156$ to $2,00,632)$ & 0.1781 & $8,02,538(4,61,390-1,143,685)$ & 0.0001 & $94,064(39,659-1,48,469)$ & 0.0015 \\
\hline Progressive motility ${ }^{\mathrm{a}}$ & $82,652(-20,842$ to $1,86,147)$ & 0.1127 & $6,49,692(3,55,208-9,44,176)$ & 0.0001 & $44,795(-2169$ to 91,758$)$ & 0.0607 \\
\hline Viability $^{a}$ & $1,23,403$ ( -7048 to $2,53,853)$ & 0.0627 & $7,82,244(4,11,058-1,153,430)$ & 0.0002 & $47,977(-11,218$ to $1,07,173)$ & 0.1077 \\
\hline Normal morphology ${ }^{a}$ & $-5386(-1,21,992$ to $1,11,220)$ & 0.9251 & $6,08,177(2,76,385-9,39,969)$ & 0.0009 & $1,03,614(50,701-1,56,528)$ & 0.0004 \\
\hline Acrosome defects ${ }^{b}$ & $-0.6213(-1.3876$ to 0.1451$)$ & 0.1076 & $-0.7251(-2.9057$ to 1.4555$)$ & 0.5003 & $-0.4135(-0.7613$ to -0.0658$)$ & 0.0216 \\
\hline $\begin{array}{l}\text { Normal tail mem- } \\
\text { brane integrity }^{\mathrm{a}}\end{array}$ & $-85,817(-2,25,635$ to 54,001$)$ & 0.2183 & $5,05,314(1,07,474-9,03,153)$ & 0.0148 & $70,115(6669-1,33,561)$ & 0.0316 \\
\hline DNA fragmentation & $-3.5201(-6.4732$ to -0.5670$)$ & 0.0213 & -6.2227 ( -14.6255 to 2.1802$)$ & 0.1400 & $-1.0848(-2.4249$ to 0.2552$)$ & 0.1081 \\
\hline \multicolumn{7}{|l|}{ Frozen-thawed semen } \\
\hline Motility $^{a}$ & $38,919(-75,091$ to $1,52,930)$ & 0.4891 & $7,81,556(4,57,150-1,105,962)$ & 0.0000 & $71,343(19,608-123,078)$ & 0.0088 \\
\hline Progressive motility ${ }^{\mathrm{a}}$ & $4328(-65,223$ to 73,878$)$ & 0.8992 & $2,33,317(35,418-4,31,216)$ & 0.0226 & $52,522(20,962-84,083)$ & 0.0021 \\
\hline$V_{\text {Viability }}{ }^{a}$ & $67,129(-72,219$ to $2,06,477)$ & 0.3312 & $6,34,447(2,37,944-1,030,950)$ & 0.0029 & $95,076(31,843-1,58,309)$ & 0.0047 \\
\hline Normal morphology ${ }^{a}$ & $-59,182(-1,73,925$ to 55,561$)$ & 0.2988 & $5,48,513(2,22,021-8,75,005)$ & 0.0019 & $91,924(39,856-1,43,992)$ & 0.0012 \\
\hline Acrosome defects ${ }^{b}$ & $0.0237(-0.4278$ to 0.4752$)$ & 0.9149 & $-1.2739(-2.5585$ to 0.0107$)$ & 0.0518 & $-0.1664(-0.3713$ to 0.0385$)$ & 0.1070 \\
\hline $\begin{array}{l}\text { Normal tail mem- } \\
\text { brane integrity }^{\mathrm{a}}\end{array}$ & $-19,935(-1,43,509$ to $1,03,638)$ & 0.7428 & $8,14,528(4,62,911-1,166,146)$ & 0.0001 & $47,923(-8152$ to $1,03,998)$ & 0.0907 \\
\hline DNA fragmentation & $-1.5635(-5.6921$ to 2.5652$)$ & 0.4434 & $-13.9299(-25.6775$ to -2.1822$)$ & 0.0219 & $-2.4675(-4.3410$ to -0.5940$)$ & 0.0118 \\
\hline
\end{tabular}

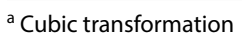

${ }^{\mathrm{b}}$ Log transformation 
Moreover, Parillo et al. [34] reported that strong expression signals of GPX4 protein were observed in the apical region of seminiferous tubules in bulls. These dynamic signals at different stages of sperm maturation suggest that GPX4 is essential for optimal bovine sperm development and function and that Se deficiency may lead to impaired spermatogenesis [34]. However, this last phase of spermatogenesis in bulls lasts 17 days; therefore, the concentration of microelements measured in the blood serum on the day of sperm collection could not truly be correlated with spermatogenesis itself. Since all bulls were fed the same diet, we believe that the same observations would be found even if the blood serum had been collected before sperm collection; however, this assumption should be tested in a future study. The statistically significant difference in Se concentration in blood serum between bulls in the SAT and UNSAT groups in our study could also be explained by the strong expression of GPX4 in epididymal fluid, prostatic fluid and seminal vesicular fluid in fertile bulls [34].

Additionally, $\mathrm{Zn}$ measured in blood serum was associated with almost all quality characteristics of fresh semen and all quality characteristics of frozen-thawed semen characteristics in our study. Moreover, when we established significant differences among trace elements between the SAT and UNSAT groups, Zn measured in blood serum was significantly higher in the SAT group. Similar to our results, $\mathrm{Zn}$ deficiency also caused reduced male fertility in the study by Kerns et al. [35]. Zn is involved in epididymal sperm maturation and capacitation [35], and its higher concentrations in seminal plasma positively correlate with progressive motility [36]. Additionally, $\mathrm{Zn}$ measured in blood serum was associated with almost all fresh semen quality characteristics and all thawed semen quality characteristics in our study. Moreover, when we found a significant difference between trace elements between the SAT and UNSAT groups, $\mathrm{Zn}$ measured in blood serum was significantly higher in the SAT group. Similar to our results, Zn deficiency also caused reduced male fertility in the study by Kerns et al. [35]. Since $\mathrm{Zn}$ is involved in epididymal sperm maturation and capacitation [35] and its higher concentrations in seminal plasma positively correlate with progressive motility [36], the association between blood serum $\mathrm{Zn}$ concentration and semen quality is consistent with better semen characteristics in our study, in which a higher proportion of morphologically normal sperm (in fresh and freeze-thawed semen), a higher proportion of sperm with intact tail membrane integrity, and progressively motile sperm (in freeze-thawed semen) were observed. Our results suggest that $\mathrm{Zn}$ measured in blood serum may be a good predictor of sperm quality characteristics after freezing and thawing.
In the male reproductive system, Fe can play either a positive or negative role depending on the Fe concentration. Increased Fe concentration in rat testes was associated with oxidative damage to lipids, proteins, and DNA [37]. On the other hand, Fe deficiency reduced the activity of Fe-containing and Fe-dependent enzymes [15]. In our study, Fe measured in blood serum and seminal plasma was positively associated with better maintenance of semen quality characteristics. More specifically, Fe in blood serum was positively associated with viability and negatively associated with the proportion of spermatozoa with acrosome defects and DNA fragmentation. Fe measured in seminal plasma was positively associated with motility, progressive motility, viability, morphologically normal spermatozoa, and spermatozoa with normal tail membrane integrity. Similarly, a negative association with acrosome defects was observed. Higher motility and viability are consistent with the study of Eghbali et al. [38], where the Fe concentration in seminal plasma was associated with the motility and viability of the spermatozoa after ejaculation. In our previous study investigating microelements in the seminal plasma of boars, a higher Fe content was associated with a higher percentage of live spermatozoa and spermatozoa with normal morphology after 3 days of storage [16]. In bulls, the addition of $\mathrm{FeCl}_{2}$ to diluted semen samples at concentrations above $50 \mu \mathrm{mol} / \mathrm{L}$ was shown to result in a significant decrease in sperm motility and mitochondrial activity. However, concentrations below $10 \mu \mathrm{mol} / \mathrm{L} \mathrm{FeCl}_{2}$ stimulated spermatozoa activity, as evidenced by significant preservation of motility and viability characteristics in dilute bull spermatozoa [9]. In our study, when the mean Fe concentration in bull seminal plasma was $2.65 \mathrm{mg} / \mathrm{L}$, higher $\mathrm{Fe}$ levels correlated with better semen quality. From multivariate analysis, Fe also affected the tail membrane and DNA integrity. Spermatozoa are under increased oxidative stress during storage [39]; therefore, low Fe concentrations may result in lower activity of Fe-dependent enzymes such as catalase [15]. These factors could cause an increase in lipid peroxidation in bull spermatozoa and lead to reduced viability.

In our study, positive correlations between element concentrations in seminal plasma and serum were significant only for $\mathrm{Cu}, \mathrm{Fe}$, and $\mathrm{Na}$ levels. A positive correlation for Fe was also found in the study of Dhami et al. [40]; however, a negative association between blood and semen elements was also found for $\mathrm{Cu}$ and $\mathrm{Zn}$ levels in their study. The exact mechanism by which elements are transferred from circulating blood to seminal plasma is unclear [41]. In agreement with other studies in humans, in which the relationship between elements in blood and in semen plasma has not been confirmed [42, 43], no significant correlations were found between $\mathrm{Se}$ 
concentration in blood and Se concentration in seminal plasma in a study conducted in stallions [44].

A recent study showed that spermatozoa from individual bulls differ in their ability to survive cryopreservation [45]. In our study, bulls that met all the requirements for semen characteristics had higher $\mathrm{Zn}$ and Se concentrations in blood serum and higher Fe concentrations in seminal plasma compared to bulls that did not meet at least one of the requirements for good semen characteristics. Therefore, the concentrations of $\mathrm{Zn}, \mathrm{Se}$ and Fe in the blood serum and $\mathrm{Zn}$ Fe in the seminal plasma of bulls can serve as freezability biomarkers.

\section{Conclusions}

Microelements in bull seminal plasma have been associated with bull sperm quality and could be used as an additional tool to predict semen quality after thawing. Due to the significant correlations between $\mathrm{Fe}, \mathrm{Zn}$ and Se concentrations in blood serum and in fresh seminal plasma and semen characteristics after thawing, measurements of the elements may be useful to discriminate between high- and low-freezability semen samples.

\section{Acknowledgements}

This work was supported by the Slovenian Research Agency and was part of 'Endocrine, immune, nervous and enzyme responses in healthy and sick animals' (P4-0053) and 'Animal Health, Environment and Food Safety' (P4-0092).

\section{Authors' contributions}

MZP, PZ and JM participated in the conceptualization and design of the study. MZP and JM preformed semen analysis. BJS and KPV performed microelement analysis. TK and PZ performed the statistical analysis. MZP wrote the original draft. PZ, JM, KPV, TK, BJS review and edit the manuscript. All authors read and approved the final manuscript.

\section{Funding}

This work was supported by the Slovenian Research Agency and was part of 'Endocrine, immune, nervous and enzyme responses in healthy and sick animals' (P4-0053) and 'Animal Health, Environment and Food Safety' (P4-0092).

\section{Availability of data and materials}

The datasets used and/or analyzed during the current study are available from the corresponding author on reasonable request.

\section{Declarations}

Ethics approval and consent to participate

Ethics approval was not needed for this study.

\section{Consent for publication}

Not applicable.

\section{Competing interests}

The authors report no competing interests. The authors alone are responsible for the content and writing of the paper.

\section{Author details}

${ }^{1}$ Clinic for Reproduction and Large Animals, Veterinary Faculty, University of Ljubljana, Gerbičeva 60, 1000 Ljubljana, Slovenia. ${ }^{2}$ Institute of Preclinical Sciences, Veterinary Faculty, University of Ljubljana, Gerbičeva 60, 1000 Ljubljana, Slovenia. Institute of Food Safety, Feed and Environment, Veterinary Faculty, University of Ljubljana, Gerbičeva 60, 1000 Ljubljana, Slovenia.
Received: 16 December 2020 Accepted: 25 June 2021

Published online: 05 July 2021

\section{References}

1. Barth A. Review: The use of bull breeding soundness evaluation to identify subfertile and infertile bulls. Animal. 2018;12:158-64.

2. Ugur MR, Saber Abdelrahman A, Evans HC, Gilmore AA, Hitit M, Arifiantini $\mathrm{Rl}$, et al. Advances in cryopreservation of bull sperm. Front Vet Sci. 2019;6:268.

3. Fair S, Lonergan P. Review: understanding the causes of variation in reproductive wastage among bulls. Animal. 2018;12:53-62.

4. Singh AK, Rajak SK, Kumar P, Kerketta S, Yogi RK. Nutrition and bull fertility: a review. J Entomol Zool Stud. 2018;6:635-43.

5. Rahman MS, Kwon WS, Pang MG. Prediction of male fertility using capacitation-associated proteins in spermatozoa. Mol Reprod Dev. 2017:84:749-59.

6. Kasimanickam RK, Kasimanickam VR, Arangasamy A, Kastelic JP. Sperm and seminal plasma proteomics of high-versus low-fertility Holstein bulls. Theriogenology. 2019;126:41-8.

7. Khalil WA, El-Harairy MA, Zeidan AEB, Hassan MAE. Impact of selenium nano-particles in semen extender on bull sperm quality after cryopreservation. Theriogenology. 2019:126:121-7.

8. Barbato V, Talevi R, Braun S, Merolla A, Sudhakaran S, Longobardi S, et al. Supplementation of sperm media with zinc, D-aspartate and co-enzyme Q10 protects bull sperm against exogenous oxidative stress and improves their ability to support embryo development. Zygote. 2017:25:168-75.

9. Tvrdá E, Kňažická Z, Lukáčová J, Schneidgenová M, Goc Z, Greń A, et al. The impact of lead and cadmium on selected motility, prooxidant and antioxidant parameters of bovine seminal plasma and spermatozoa. J Environ Sci Health A Tox Hazard Subst Environ Eng. 2013:48:1292-300.

10. Balamurugan B, Ramamoorthy M, Ravi J, Keerthana G, Gopalakrishnan KM, Kavya KM, et al. Mineral an important nutrient for efficient reproductive health in dairy cattle. Int J Environ Sci Technol. 2017;6:694-701.

11. Kumar N, Verma RP, Singh LP, Varshney VP, Dass RS. Effect of different levels and sources of zinc supplementation on quantitative and qualitative semen attributes and serum testosterone level in crossbred cattle (Bos indicus $\times$ Bos taurus) bulls. Reprod Nutr Dev. 2006;46:663-75.

12. Sordillo LM, Aitken SL. Impact of oxidative stress on the health and immune function of dairy cattle. Vet Immunol Immunopathol. 2009;128:104-9.

13. Aguiar GF, Batista BL, Rodrigues JL, Silva LR, Campiglia AD, Barbosa RM, et al. Determination of trace elements in bovine semen samples by inductively coupled plasma mass spectrometry and data mining techniques for identification of bovine class. J Dairy Sci. 2012;95:7066-73.

14. Mirnamniha M, Faroughi F, Tahmasbpour E, Ebrahimi P, Beigi HA. An overview on role of some trace elements in human reproductive health, sperm function and fertilization process. Rev Environ Health. 2019:34:339-438.

15. Massanyi P, Trandzik J, Nad P, Toman R, Skalick M, Kornekov B. Seminal concentrations of trace elements in various animals and their correlations. Asian J Androl. 2003;5:101-4.

16. Zakošek Pipan M, Mrkun J, Strajn BJ, Vrtač KP, Kos J, Pišlar A, et al. The influence of macro- and microelements in seminal plasma on diluted boar sperm quality. Acta Vet Scand. 2017:59:11.

17. Indriastuti $R$, Ulum MF, Arifiantini Rl, Purwantara B. Individual variation in fresh and frozen semen of Bali bulls (Bos sondaicus). Vet World. 2020;13:840-6.

18. Mehdi Y, Dufrasne I. Selenium in cattle: a review. Molecules. 2016;23:545.

19. El-Sharawy M, Eid E, Darwish S, Abdel-Razek I, Islam MR, Kubota K, et al. Effect of organic and inorganic selenium supplementation on semen quality and blood enzymes in buffalo bulls. Anim Sci J. 2017;88:999-1005.

20. Anchordoquy JP, Anchordoquy JM, Lizarraga RM, Nikoloff N, Pascua AM, Furnus CC. The importance of trace minerals copper, manganese, selenium and zinc in bovine sperm—zona pellucida binding. Zygote. 2019;27:1-8.

21. Hidiroglou M. Trace element deficiencies and fertility in ruminants: a review. J Dairy Sci. 1979;62:1195-206. 
22. Arthington JD, Corah LR, Hill DA. Case study: the effect of dietary zinc level and source on yearling bull growth and fertility. Prof Anim Sci. 2002;18:282-5.

23. Zezeski AL, Van Emon ML, Waterman RC, Eik BA, Heldt JS, Geary TW. Impacts of zinc, manganese, and copper source on mature bull trace mineral status and spermatozoa characteristics. Anim Sci. 2016;94(5):609.

24. Geary TW, Waterman RC, Van Emon ML, Ratzburg CR, Lake S, Eik BA, et al. Effect of supplemental trace minerals on novel measures of bull fertility. Transl Anim Sci. 2019;16:1813-7.

25. Liu H, Sun Y, Zhao J, Dong W, Yang G. Effect of zinc supplementation on semen quality, sperm antioxidant ability, and seminal and blood plasma mineral profiles in cashmere goats. Biol Trace Elem Res. 2020;196:438-45.

26. Geary TW, Kelly WL, Spickard DS, Larson CK, Grings EE, Ansotegui RP. Effect of supplemental trace mineral level and form on peripubertal bulls. Anim Reprod Sci. 2016;168:1-9.

27. Tsuneda PP, Tsuneda BH, Hatamoto-Zervoudakis LK, Zervoudakis JT, Santos Marinho WA, Duarte Júnior MF, et al. Dietary selenium supplementation and sperm quality in Brangus bulls semen. Ciênc anim bras. 2019. https://doi.org/10.1590/1089-6891v20e-48586.

28. Bartle JL, Senger PL, Hillers JK. Influence of injected selenium in dairy bulls on blood and semen selenium, glutathione peroxidase and seminal quality. Biol Reprod. 1980;23:1007-13.

29. Pal RP, Mani V, Mir SH, Singh RK, Sharma R. Importance of trace minerals in the ration of breeding bull_-a review. Int J Curr Microbiol App Sci. 2017:6:218-24.

30. Ledoux DR, Shannon MC. Bioavailability and antagonists of trace minerals in ruminant metabolism. Proc Florida Rum Nut Symp 2005. Accessed Aug. 3, 2013. http://dairy.ifas.ufl.edu/rns/2005/Ledoux.pdf.

31. Jamali NU, Kaka A, Khatri P, Malhi M, Naeem M, Memon AA, et al. Effect of in vitro selenium addition to the semen extender on the spermatozoa characteristics before and after freezing in Kundhi buffalo bull and in vivo fertility rate. Pakistan J Zool. 2019;51:317-23.

32. Qazi IH, Angel C, Yang H, Zoidis E, Pan B, Wu Z, et al. Role of selenium and selenoproteins in male reproductive function: a review of past and present evidences. Antioxidants. 2019:2:8.

33. Lasota B, Błaszczyk B, Seremak B, Udała J. Selenium status and GSH-PX activity in semen and blood of boars at different ages used for artificial insemination. Reprod Dom Anim. 2004;39:309-14.

34. Parillo F, Sylla L, Palombi C, Monaci M, Stradaioli G. Immunocytochemical localisation of phospholipid hydroperoxide glutathione peroxidase in bull's spermatogenic cells. Ital J Anim Sci. 2014;13:3483.
35. Kerns K, Zigo M, Sutovsky P. Zinc: a necessary ion for mammalian sperm fertilization competency. Int J Mol Sci. 2018;19:4097.

36. Li Y, Kalo D, Zeron Y, Roth Z. Progressive motility - a potential predictive parameter for semen fertilization capacity in bovines. Zygote. 2016:24:70-82

37. Marchlewicz M, Wiszniewska B, Gonet B, Baranowska-Bosiacka I, Safranow K, Kolasa A, et al. Increased lipid peroxidation and ascorbic acid utilization in testis and epididymis of rats chronically exposed to lead. Biometals. 2007:20:13-9.

38. Eghbali M, Alavi-Shoushtari MZ, Asri-Rezaei S, Ansari MHK. Effects of the seminal plasma iron and lead content on semen quality of water buffalo (Bubalus Bubalis) bulls and their relationships with semen characteristics. Vet Res For. 2010;1:12-20.

39. Kumaresan A, Kadirvel G, Bujarbaruah KM, Bardoloi RK, Das A, Kumar $\mathrm{S}$, et al. Preservation of boar semen at $18^{\circ} \mathrm{C}$ induces lipid peroxidation and apoptosis like changes in spermatozoa. Anim Reprod Sci. 2009;110:162-71.

40. Dhami AJ, Shelke VB, Patel KP, Paradva JP, Kavani FS. Trace minerals profile of blood and seminal plasma of breeding bulls. Indian J Anim Sc. 2001;71:761-3.

41. Wong WY, Flik G, Groenen PMW, Swinkels DW, Thomas CMG, Copius-Peereboom JHJ, et al. The impact of calcium, magnesium, zinc, and copper in blood and seminal plasma on semen parameters in men. Reprod Toxicol. 2001;15:131-6.

42. Sørensen MB, Bergdahl IA, Hjøllund NH, Bonde JPE, Stoltenberg M, Ernst E. Zinc, magnesium and calcium in human seminal fluid: relations to other semen parameters and fertility. Mol Hum Reprod. 1999;5:331-7.

43. Salsabili N, Mehrsai AR, Jalaie S. Concentration of blood and seminal plasma elements and their relationships with semen parameters in men with spinal cord injury. Andrologia. 2009;41:24-8.

44. Bertelsmann $H$, Keppler $\mathrm{S}$, Höltershinken M, Bollwein $H$, Behne D, Alber $D$, et al. Selenium in blood, semen, seminal plasma and spermatozoa of stallions and its relationship to sperm quality. Reprod Fertil Dev. 2010;22:886-91.

45. Ryu DY, Song WH, Pang WK, Yoon SJ, Rahman MS, Pang MG. Freezability biomarkers in bull epididymal spermatozoa. Sci Rep. 2019;9:12797.

\section{Publisher's Note}

Springer Nature remains neutral with regard to jurisdictional claims in published maps and institutional affiliations.
Ready to submit your research? Choose BMC and benefit from:

- fast, convenient online submission

- thorough peer review by experienced researchers in your field

- rapid publication on acceptance

- support for research data, including large and complex data types

- gold Open Access which fosters wider collaboration and increased citations

- maximum visibility for your research: over $100 \mathrm{M}$ website views per year

At BMC, research is always in progress.

Learn more biomedcentral.com/submissions 